\title{
Pendidikan Kesehatan Reproduksi: Bahaya Pernikahan Dini
}

\author{
Mira Eka Puspita, Ade Ramdan Gumelar, Lusi Fitriah Sari, Mamlukah, Rosi Suparman, \\ Susianto \\ STIKes Kuningan \\ miraekapuspita20@gmail.com
}

\begin{abstract}
Abstrak
Pendahuluan: Permasalahan kesehatan reproduksi pada remaja salah satu diantaranya adalah kehamilan di usia muda yang bisa bersumber dari pernikahan usia dini, Pernikahan dini merupakan masalah global yang masih ditemukan di berbagai negara berkembang, termasuk Indonesia. Tujuan: Untuk mengetahui pengaruh Pendidikan Kesehatan terhadap pengetahuan kesehatan reproduksi pada santri SMKIT Binaul Ummah Kuningan. Metode: Penelitian praeksperimen dilakukan kepada santri SMKIT Binaul Ummah Kuningan dengan metode pengambilan sampel denga total sampling sebanyak 39 responden, untuk memperoleh hasil penelitian digunakan analisa uji $\mathrm{T}$ pada pretest dan post test dengan $P$ value $<0,05$. Hasil: Diperoleh hasil perhitungan uji statistik dengan menggunakan komputerisasi, diperoleh nilai $\mathrm{t}$ sebesar $-10,211$ dan $\mathrm{p}=0,000(\mathrm{p}<0,05)$. Kesimpulan: Terdapat pengaruh pendidikan kesehatan terhadap pengetahuan santri SMKIT Binaul Ummah Kuningan.
\end{abstract}

Kata kunci: Kesehatan Reproduksi. Pendidikan Kesehatan, Pernikahan Dini

\section{PENDAHULUAN}

Kesehatan reproduksi merupakan suatu keadaan sejahtera fisik, mental dan sosial secara utuh tidak semata-mata bebas dari penyakit atau kecacatan dalam suatu yang berkaitan dengan sistem reproduksi, fungsi dan prosesnya (Adjie, 2013).

Kebijakan Nasional Kesehatan Reproduksi di Indonesia menetapkan bahwa kesehatan reproduksi mencakup 5 (lima) komponen/program terkait, yaitu Program Kesehatan Ibu dan Anak, Program Keluarga Berencana, Program Kesehatan Reproduksi Remaja, Program Pencegahan dan Penanggulangan Penyakit Menular Seksual (PMS) termasuk HIV/AIDS, dan Program Kesehatan Reproduksi pada Usia Lanjut (Hanim, 2013).

Salah satu dari pada kebijakan nasional Kesehatan Reproduksi adalah Program Kesehatan Reproduksi Remaja. Masalah reproduksi remaja selain berdampak secara fisik, juga dapat berpengaruh terhadap kesehatan mental dan emosi, keadaan ekonomi dan 
JURNAL PEMBERDAYAAN

DAN PENDIDIKAN KESEHATAN

VOL. 01 No. 01, DESEMBER 2021
Ciptaan disebarluaskan di bawah

Lisensi Creative Commons Atribusi-

NonKomersial-BerbagiSerupa 4.0

kesejahteraan sosial dalam jangka panjang. Dampak jangka panjang tersebut tidak hanya berpengaruh terhadap remaja itu sendiri, tetapi juga terhadap keluarga, masyarakat dan bangsa pada akhirnya. Permasalahan kesehatan reproduksi pada remaja dapat dikelompokkan diantaranya yaitu perilaku berisiko, kurangnya akses pelayanan kesehatan, kurangnya informasi yang benar dan dapat dipertanggungjawabkan, banyaknya akses pada informasi yang salah tanpa tapisan, masalah PMS termasuk infeksi HIV/AIDS, tindak kekerasan seksual, seperti pemerkosaan, pelecehan seksual dan transaksi seks komersial, kehamilan dan persalinan usia muda yang berisiko kematian ibu dan bayi, serta kehamilan yang tak dikehendaki, yang sering kali menjurus kepada aborsi yang tidak aman dan komplikasinya (Hanim, 2013).

Beberapa penelitian membuktkan bahwa permasalahan yang muncul pada kesehatan reproduksi bisa disebabkan oleh adanya pernikahan usia muda atau pernikahan usia dini dan memunculkan banyak resiko. Pernikahan dini adalah sebuah pernikahan yang dilakukan sebelum umur 19 tahun. Batasan umur ini merujuk pada Undang-Undang Nomor 16 Tahun 2019 tentang Perubahan atas UndangUndang Nomor 1 Tahun 1974 tentang Perkawinan. Pernikahan dini merupakan masalah global yang masih ditemukan di berbagai negara berkembang, termasuk Indonesia. Studi sebelumnya menunjukkan bahwa rata-rata umur pernikahan dini di Kosovor-Albania adalah 17,3 tahun, sementara di Barat Laut Ethiopia adalah 17 tahun. Hasil Survei Demografi Kesehatan Indonesia (SDKI) tahun 2012 menunjukkan bahwa diperkirakan 17 persen anak perempuan menikah di usia kurang dari 18 tahun di Indonesia. Selanjutnya SDKI tahun 2017 melaporkan terjadinya perubahan tren pernikahan yaitu 63,7 persen anak perempuan Indonesia menikah pada usia 20 tahun (SDKI, 2020).

Pendidikan kesehatan reproduksi di Indonesia belum banyak dilakukan. Pendidikan kesehatan reproduksi tidak tercakup di dalam kurikulum sekolah seperti yang direkomendasikan oleh WHO, karena adanya konflik antara nilai tradisi Indonesia dengan globalisasi kebarat-baratan yang dianggap muncul seiring adanya pendidikan kesehatan reproduksi, Oleh sebab itu kasus-kasus yang berhubungan dengan kesehatan reproduksi di Indonesia masih tinggi, dengan dibuktikan banyaknya perceraian yang terjadi di usia 20 sampai 24 tahun dengan batas pernikahan tidak sampai 5 Tahun (BKKBN, 2018). 
JURNAL PEMBERDAYAAN

DAN PENDIDIKAN KESEHATAN

VOL. 01 No. 01, DESEMBER 2021
Ciptaan disebarluaskan di bawah

Lisensi Creative Commons Atribusi-

NonKomersial-BerbagiSerupa 4.0

Berdasarkan data dari SDKI tahun 2012 dan 2017 angka kelahiran pada wanita usia 15-19 tahun, Jawa Barat mengalami kenaikan yaitu dari 35 ke 38 meskipun pada data hasil survei ditemukan angka mematian ibu saat melahirkan disaat umur ibu kurang dari 20 tahun mengalami penurunan dari 50 ke 34. (SDKI, 2020)

Menurut Teori Arikunto (2006) penentuan tingkat pengetahuan responden dibagi dalam 3 kategori, yaitu baik, cukup, dan kurang. Kategori baik jika subjek mampu menjawab dengan benar sebanyak 76\%-100\% dari seluruh pertanyaan. Dan dikatakan pengetahuannya cukup bila subjek mampu menjawab dengan benar sebanyak 56\%-75\% dari seluruh pertanyaan dan ketika dikatakan pengetahuan kurang adalah apabila subjek mampu menjawab dengan benar $<56 \%$ dari seluruh pertanyaan (Zainurahma, 2018).

SMKIT Binaul Ummah merupakan sekolah yang didirikan pertama kali pada tahun 2019, dimana tahun 2021 sekarang merupakan tahun pertama meluluskan dan baru akan terdaftar di Dapodik. Dari jumlah santri sebanyak 62 orang pada 3 angkatan dengan keseluruhan berjenis kelamin perempuan belum sama sekali mendapatkan edukasi dari pihakpihak terkait.

Berdasarkan hal-hal tersebut, penulis ingin mengetahui adakah pengaruh pendidikan kesehatan reproduksi remaja terhadap tingkat pengetahuan tentang kesehatan reproduksi pada santri SMKIT Binaul Ummah Kuningan.

\section{MASALAH}

SMKIT berdiri pada tahun 2019 dengan jumlah santri sebanyak 62 orang yang terdiri dari 23 santri kelas XII, 26 Orang kelas XI, dan 13 Orang kelas X, dimana secara keseluruhan belum diinput di Data Pokok Peserta Didik sehingga untuk SMKIT sama sekali belum pernah menjadi sasaran program edukasi kesehatan reproduksi dari puskesmas wilayah kerjanya.

\section{METODE PELAKSANAAN}

Metode yang digunakan adalah metode pendidikan masyarakat yaitu dengan memberikan penyuluhan dengan tujuan untuk meningkatkan pemahaman para santri SMKIT Pondok Pesantren Binaul Ummah Kuningan. Penelitian ini menggunakan praeksperimen (quasi eksperimen), penelitian ini dengan rancangan pre-post test dalam satu kelompok (onegroup pre-post test desigen).

Penelitian dilakukan selama satu hari pada tanggal 22 November 2021, dimana sampel pada penelitian ini adalah 39 orang dari populasi sebanyak 62 orang dengan tehnik 
JURNAL PEMBERDAYAAN

DAN PENDIDIKAN KESEHATAN

VOL. 01 No. 01, DESEMBER 2021
Ciptaan disebarluaskan di bawah

Lisensi Creative Commons Atribusi-

NonKomersial-BerbagiSerupa 4.0

pengambilan sampel adalah total sampling, Instrumen yang digunakan adalah kuisioner dengan 10 pertanyaan pengetahuan. Responden diberikan pretest dan post test tentang pengetahuan kesehatan reproduksi dengan spesifikasi pertanyan pengetahuan pernikahan dini.

Untuk mengetahui hasil sebelum dan sesudah dilakukan pendidikan kesehatan analisa data yang digunakan adalah Uji Beda Mean Dependent (Faired Test) . Pertama kali adalah menganalisis data menggunakan univariat untuk menghasilkan distribusi frekuensi dan presentase dan analisis bivariat menggunakan uji paired t-test dengan uji prasyarat yang harus dipenuhi yaitu normalitas dengan menggunakan uji wilcoxon diperoleh signifikasi 0,000 $(\mathrm{p}<0,05)$ Untuk melihat pengaruh pendidikan kesehatan tentang kesehatan reproduksi terhadap pengetahuan Santri SMKIT Pondok Pesantren Binaul Ummah Kuningan.

\section{HASIL DAN PEMBAHASAN}

Distribusi frekuensi responden berdasarkan kategori hasil pretest, dapat dilihat pada tabel sebagai berikut:

Tabel 1. Distribusi Frekuensi Responden Berdasarkan Pengetahuan Hasil Pretest.

\begin{tabular}{ccc}
\hline Kategori & Frekuesi & Persentasi (\%) \\
\hline Kurang & 31 & 79.5 \\
Cukup & 7 & 17.9 \\
Baik & 1 & 2.6 \\
\hline Total & $\mathbf{3 9}$ & $\mathbf{1 0 0}$ \\
\hline
\end{tabular}

Berdasarkan tabel 1. Dari 39 responden yang mengikuti pretest, sebagian besar responden mempunyai pengetahuan kurang sebanyak 31 orang $(79.5 \%)$.

Tabel 2. Distribusi Frekuensi Responden Berdasarkan Pengetahuan Hasil Post test

\begin{tabular}{ccc}
\hline Pengetahuan & Mean & Standar Deviasi \\
\hline Pengetahuan pretest & 1.23 & 0.485 \\
Pengetahuan post test & 2.54 & 0.756 \\
\hline
\end{tabular}

Berdasarkan tabel 2. Dari 39 responden yang mengikuti post test, sebagian besar responden mempunyai pengetahuan Baik sebanyak 27 orang $(69,2 \%)$. 
JURNAL PEMBERDAYAAN

DAN PENDIDIKAN KESEHATAN

VOL. 01 No. 01, DESEMBER 2021
Ciptaan disebarluaskan di bawah

Lisensi Creative Commons AtribusiNonKomersial-BerbagiSerupa 4.0

Tabel 3. Skor Pretest dan Post test.

\begin{tabular}{ccc}
\hline Kategori & Frekuesi & Persentasi (\%) \\
\hline Kurang & 6 & 15.4 \\
Cukup & 6 & 15.4 \\
Baik & 27 & 69.2 \\
\hline Total & $\mathbf{3 9}$ & $\mathbf{1 0 0}$ \\
\hline
\end{tabular}

Berdasarkan Tabel 3. Berdasarkan uji analisis sample paired test yang diperoleh dapat dilihat rata-rata skor rata-rata hasil pretest sebesar 1,23 menjadi 2,54 dengan jumlah kenaikan point 1,31 .

Tabel 4. Hasil Analisis Uji T Pengetahuan Santri tentang Kesehatan reproduksi bahaya Pernikahan Dini.

\begin{tabular}{lccc}
\hline \multicolumn{1}{c}{ Pengetahuan } & $\begin{array}{c}\text { Rata-rata } \\
\text { selisih }\end{array}$ & Nilai $\boldsymbol{T}$ & $\boldsymbol{P}$ Value \\
\hline $\begin{array}{l}\text { Pengetahuan pretest } \\
\text { Pengetahuan Post test }\end{array}$ & -1.308 & -10.211 & .000 \\
\hline
\end{tabular}

Berdasarkan tabel 4 diperoleh hasil perhitungan uji statistik dengan menggunakan komputerisasi, diperoleh nilai $\mathrm{t}$ sebesar $-10,211$ dan $\mathrm{p}=0,000(\mathrm{p}<0,05)$, artinya ada pengaruh pendidikan kesehatan tentang kesehatan reproduksi bahaya Pernikahan Dini terhadap pengetahuan santri

Berdasarkan pemaparan yang disampaikan oleh pendamping asrama santri sejauh ini belum pernah diberikan edukasi terkait kesehatan reproduksi apalagi terkait pernikahan dini, mengingat jurusan pada sekolah tersebut merupakan sekolah dengan jurusan laboratorium medik dan tata boga meskipun secara keseluruhan merupakan santri perempuan akan tetapi karena materi tersebut tidak terdapat pada pembelajaran jadi ada kesulitan dalam penyampaian edukasi tersebut.

Pemahaman santri bisa bertambah dengan adanya edukasi tersebut melalui presentasi atau pemaparan materi bahaya pernikahan dini, penyampaian video pembelajaran serta diskusi dan tanya jawab terkait materi bahaya pernikahan dini tersebut. Hasil penelitian menunjukkan bahwa hasil post test lebih baik daripada hasil pretest, hal ini disebabkan karena adanya suatu perlakuan yaitu sebelum post test para santri diberikan pendidikan kesehatan dengan metode-metode tersebut. 
JURNAL PEMBERDAYAAN

DAN PENDIDIKAN KESEHATAN

VOL. 01 No. 01, DESEMBER 2021
Ciptaan disebarluaskan di bawah

Lisensi Creative Commons Atribusi-

NonKomersial-BerbagiSerupa 4.0

Sesuai dengan teori dari Notoatmojo (2010) dalam Megawati (2016), bahwa setelah mengalami stimulus, kemudian mengadakan penilaian atau pendapat terhadap apa yang diketahui, proses selanjutnya diharapkan dapat melaksanakan atau mempraktikkan apa yang diketahui dan disikapinya (Megawati, 2016).

Suatu metode penyampaian informasi pada kelompok disesuaikan dengan kelompok tersebut, metode dengan presentasi akan cocok pada usia menengah keatas sehingga penulis mengambil metode tersebut untuk menstimulus pengetahuan para santri, selain itu dikarenakan peserta lebih dari 15 orang maka tergolong pada kelompok besar sehingga penulis menggunakan metode ceramah tanya jawab. Hal ini sesuai dengan apa yang disampaikan ahli bahwa metode ceramah merupakan metode yang boleh dikatakan sebagai metode tradisional, karena sejak dulu metode ini telah dipergunakan sebagai alat komunikasi lisan antara guru dengan anak didiknya dalam proses belajar mengajar. Metode ceramah baik digunakan apabila peserta penyuluhan lebih dari lima belas orang, sasaran yang berpendidikan tinggi maupun yang berpendidikan rendah sehinga metode ini lebih banyak menuntut keaktifan dari guru daripada anak didiknya (Megawati, 2016).

Pada hasil diperoleh bahwa adanya kenaikan poin sebesar 1,31 pada angka skor ratarata hasil pretest dan post test, disini membuktikan bahwa ada perubahan setelah dilaksanakan presentasi dan diskusi tanya jawab. Sehingga dapat diperoleh hasil terakhir bahwa ada pengaruh pendidikan kesehatan terhadap pengetahuan santri yang dibuktikan dengan hasil uji dengan menggunakan paired t test diperoleh t hitung sebesar -10,211 dengan nilai $p$ value 0,000. Dengan dibuktikan bahwa terdapat perbedaan yang nyata antara pretest dan post test. Sehingga hasil penelitian ini sejalan dengan penelitian Nurjanah (2014) menunjukkan ada perbedaan yang signifikan antara kecenderungan perilaku seksual sebelum dan setelah diberi pendidikan kesehatan reproduksi dengan nilai Z sebesar - $3.027(\mathrm{p}=0,001)$. Nilai rerata pada pretest $=100,22$ dan rerata pada post test $=95,66$ dan penelitian Meti Megawati (2016) dengan hasil perhitungan uji statistik dengan menggunakan komputerisasi, diperoleh nilai $\mathrm{t}$ sebesar 6,936 dan $\mathrm{p}=0,000(\mathrm{p}<0,05)$, artinya ada pengaruh pendidikan kesehatan tentang kesehatan reproduksi terhadap pengetahuan remaja (Megawati, 2016).

\section{KESIMPULAN DAN SARAN}

Dari penelitian yang dieproleh dengan menggunakan metode pretest dan post test dapat diperoleh bahwa ada pengaruh pendidikan kesehatan terhadap pengetahuan santri SMKIT 
JURNAL PEMBERDAYAAN

DAN PENDIDIKAN KESEHATAN

VOL. 01 No. 01, DESEMBER 2021
Ciptaan disebarluaskan di bawah

Lisensi Creative Commons Atribusi-

NonKomersial-BerbagiSerupa 4.0

Binaul Ummah dibuktikan dengan hasil sebelum dilaksanakan pendidikan Kesehatan pengetahuan dengan angka 31 atau 79,5\% santri berpengetahuan kurang dan setelah dilaksanakan pendidikan kesehatan diperoleh hasil dengan angka 27 atau 69,2\% santri berpengetahuan baik. Penulis mengharapkan ada keberlanjutan dari puskesmas setempat dalam pendidikan kesehatan reproduksi lainnya guna lebih meminimalisir resiko-resiko yang ditimbulkan dari bahaya pernikahan dini. Penulis juga merekomendasikan kepada peneliti lainnya bisa menambah jumlah instrument penelitian agar poin-poin kesehatan reproduksi bisa lebih banyak diketahui.

\section{UCAPAN TERIMA KASIH}

Penulis mengucapkan terimakasih atas dukungan dan bimbingan dari para Dosen Stikes Kuningan terutama kepada Dr. Hj Mamlukah, S.KM .M.Kes dan Dr. drg. Rosi Suparman, M.Kes., M.H. tidak lupa kepada semua sivitas akademika Yayasan Pondok Pesnatren Binaul Ummah Kuningan dan SMKIT Binaul Ummah Kuningan yang telah berkenan dijadikan tempat penelitian.

\section{DAFTAR PUSTAKA}

Adjie, J. (2013). Kesehatan Reproduksi Remaja dalam Aspek Sosial. https://www.idai.or.id/artikel/seputar-kesehatan-anak/kesehatan-reproduksi-remajadalam-aspek-sosial

BKKBN. (2018). Banyak calon pasangan yang lebih memikirkan konsep pernikahan dibandingkan kehidupan pasca-pernikahan. https://www.bkkbn.go.id/detailpost/nikahmuda

Hanim, D. (2013). Komunikasi, Informasi, Edukasi (KIE). Tim Revisi Field Lab Fakultas Kedokteran.

Megawati, M. (2016). Pendidikan Kesehatan Reproduksi Remaja Di Sekolah Menengah Pertama. Media Informasi Poltekkes Kemenkes Tasikmalaya, 12, 1-6.

Nurjanah., Y. M. (2014). Literasi Kesehatan sebagai Indikator Keberhasilan Program Pendidikan Kesehatan pada Mahasiswa. Universitas Dian Nuswantoro Semarang.

SDKI. (2020). Laporan Survei Demografi dan Kesehatan Indonesia, 2017. Badan Pusat Statistik.

Zainurahma, L. (2018). Eprint.Poltekes Jogja. http://eprints.poltekkesjogja.ac.id/2249/3/BAB II_Latifa FZ_Reg A.pdf 